\title{
U.S. Support for Afghan Women, Children, and Refugees
}

Office of International Women's Issues

Washington, DC

June 22, 2004

This report is submitted to Congress by the Department of State under the Afghan Women and Children Relief Act of 2001.

\section{Table of Contents}

1. Introduction

2. Overview of Afghan Women, Children and Refugees

3. Security Environment and Violence Against Women

4. Political and Civic Participation

5. The U.S.-Afghan Women's Council

6. Economic Sector: U.S. Development Programs for Women

7. Health Sector: Programs and Increasing Access for Women

8. Education Sector: Programs for Women and Girls

9. Afghan Children: Saving the Next Generation

10. Afghan Refugees: Returning Home

11. Conclusion: The Road Ahead

Appendix to 2004 Report to Congress Appendix Legend (List of Acronyms Used)

\section{INTRODUCTION}

This report is respectfully submitted to Congress under the provisions of Sec. 3 (2) of P.L. 107-81, The Afghan Women and Children Relief Act of 2001, as signed into law by President George W. Bush on December 12, 2001. That section reads, in pertinent part:

Beginning 6 months after the date of enactment of this Act, and at least annually for the 2 years thereafter, the Secretary of State shall submit a report to the Committee on Appropriations and the Committee on Foreign Relations of the Senate and the Committee on Appropriations and the Committee on International Relations of the House of Representatives describing the activities carried out under this Act and otherwise describing the conditions and status of women and children in Afghanistan and the persons in refugee camps while United States aid is given to displaced Afghans.

The first two such reports, each entitled "U.S. Support for Afghan Women, Children, and Refugees," were submitted to Congress in June 2002 and June 2003, respectively. The present report is the third and final one that follows up those initial assessments, at the stipulated one-year interval.

The report, prepared by the Department of State's Office of the Senior Coordinator for International Women's Issues, is organized into two main sections: a narrative analysis, including illustrative examples of specific issues and U.S. programs; and a detailed Appendix, which provides in matrix format summary information about approximately 187 ongoing or new FY 2004 individual U.S. Government-supported projects that benefit 
Afghan women, children, and refugees.

\section{OVERVIEW OF AFGHAN WOMEN, CHILDREN AND REFUGEES}

\section{Progress and Problems}

Since the Department's first Report to Congress in June 2002, many successful initiatives have been implemented by the United States and by our coalition partners in Afghanistan. These reconstruction efforts-and the courage of the people themselves--are helping to improve the daily lives of Afghan women. The job of creating an environment that allows Afghan women to participate fully in the political, economic and social life of liberated Afghanistan is far from over; but this report shows that progress is well underway. The international community has also acknowledged this progress. The December 2003 UN Secretary General's Report on Afghan Women held:

Afghan women, despite many obstacles, are playing a crucial role in building a new Afghanistan, both politically and economically. They have participated throughout the country in the consultative process in drafting the new constitution. Women continue to return to the workforce in modest numbers, gain access to education and health services, and...[were] chosen in significant number to represent their concerns and interests in the Constitutional Loya Jirga.

Since 2002, the United States has implemented well over 200 projects--the 187 new and ongoing projects detailed in the Appendix to this Report, plus approximately 30 fully completed projects-directly in support of Afghan women and girls, and many more that benefit all Afghans. These projects increase women's political participation, build civil society, create economic opportunities, support the education of girls and women, and increase access to health care. In addition, U.S. NGOs and private sector groups and organizations are making substantial contributions in all these areas.

These efforts have produced real results, creating a new, post-Taliban environment in Afghanistan where:

- Women are an integral part of the government. The Cabinet includes two women ministers - the Minister of Women's Affairs and Minister of Health. A woman heads the Afghan Independent Human Rights Commission. Many more women serve in the public and private sectors.

- Women participated in creating a new Constitution. At the Constitutional Loya Jirga, 102 of the 500 delegates were women.

- The new Afghan Constitution affords all citizens of Afghanistan - men and women - equal rights and duties before the law. The new Constitution also reserves $25 \%$ of the seats in the lower house and $17 \%$ in the upper house of Parliament for women.

- Women can register to vote and participate in the upcoming elections, scheduled for September 2004. In cities where there are U.S.-funded women's radio stations, Herat and Mazar-e-Sharif, $48 \%$ percent of women have registered to vote, nearly double the national average so far.

- Girls attend school. According to the Afghan Ministry of Education, 5.8 million children are attending school - and 35 percent are girls, by far the highest number in Afghan history.

- Refugees are returning home. Over 3 million Afghans refugees have returned to their country; about half the refugees are women and girls.

- Women can earn a livelihood, even in non-traditional ways. The Afghan Conservation Corps, under a program supported by the Department of State, employs hundreds of women to plant trees in reforestation projects, and to make nets to protect the seedlings. With other funding from the Department of State and USAID in partnership with several NGOs, women journalists and filmmakers received media training and produced "Afghanistan Unveiled," an acclaimed documentary about abuses against women by the Taliban. Women are working as police officers. They are starting their own businesses with help from micro-credit facilities. In June 2004, the U.S. Department of Agriculture sponsored 12 Afghan women for training as managers and technicians in agribusiness.

- Even in rural areas, basic health services are now available to more than 2.5 million people in 21 
provinces; 90 percent of the recipients are women and children.

As Karen Hughes, a key aide to President Bush said during the U.S.-Afghan Women's Council's 2004 trip to Afghanistan, "Last year ... the women were talking about writing a constitution; this year they have enacted one." Afghan Foreign Minister Abdullah Abdullah put it this way: "Considering where things were two years ago, the extent to which the women of Afghanistan have stood up is remarkable." Or, as one Afghan woman delegate to the Constitutional Loya Jirga proudly asserted, "We just need someone to back us up ... Now we know we are not alone."

Despite such measurable progress, the lack of education perpetuated during the Taliban years created many barriers that will take years to overcome completely. Limited employment possibilities and the security situation in some areas continue to impede the ability of many women to improve their situation. Health care also remains a major issue for many Afghan women.

The struggle to achieve rights and freedom is never easy, particularly in a country that has suffered years of war, brutal oppression and poverty. In the words of First Lady Laura Bush, at the White House ceremonies marking International Women's Day 2004: "The struggle for women's rights is a story of ordinary women doing extraordinary things. And today, the women of Afghanistan are writing a new chapter in their history."

\section{Continuing U.S. Commitment}

The United States must and will remain committed to the process of Afghan reconstruction. For well over a decade, the United States has been the leading contributor of reconstruction assistance to Afghanistan. This flow intensified greatly after the overthrow of the Taliban, with over $\$ 1.8$ billion in humanitarian and reconstruction aid delivered in FY 02 and 03. In addition, in October 2003, the United States launched the "Accelerating Success in Afghanistan" initiative. The amount of assistance increased to $\$ 2.2$ billion for FY 04 , including a major security component, related spending on infrastructure, and nearly $\$ 400$ million in democracy and governance support funds. At the April 2004 Berlin donor conference on Afghanistan, the United States also helped mobilize complementary international support, with overall pledges totaling $\$ 8.2$ billion. These longterm commitments are "front-loaded," with over half ( $\$ 4.5$ billion) due in the coming year.

The primary U.S. manager of Afghan reconstruction programs remains the U.S. Agency for International Development (USAID), which has assigned senior experts both in Washington and in Kabul to ensure that women are fully included as planners, implementers, and beneficiaries of these manifold activities. Above and beyond this overall commitment, USAID is implementing projects specifically designed to support the women of Afghanistan. USAID's overall FY 04 Afghan women's empowerment program is a mixture of components within existing programs $(\$ 65,769,000)$ and new programs $(\$ 15,000,000)$ focused on advancing the participation and voice of Afghan women in local governance, and their access to services.

With regard to Afghan women's programs, in FY 2004, the U.S. Government is helping to fund the Afghan Ministry of Women's Affairs, the U.S.-Afghan Women's Council, and a number of their particular projects as described below. At the same time, other U.S. Government programs, as well as NGO, private sectors, and public-private partnership endeavors, focus on advancing the role of Afghan women in local governance and their access to health, employment, and other services. On an even larger scale, most U.S. programs are designed to benefit both women and men, by developing Afghanistan's vital educational, medical, vocational, and infrastructure sectors. Because of the complex combination of programs it is impossible to define a distinct dollar amount devoted just to women, children, and refugees. Nonetheless, it is clear that the United States' continued assistance to Afghanistan is being implemented consistent with the principles of the Afghan women and Children Relief Act of 2001.

Over the longer term, U.S. policy supports the efforts of the Afghan government to firmly establish a democratic nation that is inhospitable to terrorism and drug trafficking, at peace with its neighbors, and able to provide for its own internal and external security. Refugees and internally displaced persons (IDPs) should be successfully reintegrated, and social indicators such as education and maternal and infant mortality must improve across the board. Human rights - including the rights of women and of religious and ethnic minorities - must be protected; freedom of conscience must be respected in law and in fact. On the economic front, the United States hopes to see an Afghanistan with a self-financing public sector and a vibrant market economy.

\section{THE SECURITY ENVIRONMENT AND VIOLENCE AGAINST WOMEN}

\section{The General Security Situation}

While security continues to be a critical concern, the United States is committed to moving ahead with the 
reconstruction of Afghanistan, in partnership with the Afghan people. The attacks from those who wish to deny freedom and the benefits of reconstruction to the Afghan people will not deter our efforts to assist them. In fact, as a result of U.S. and Afghan efforts, the security situation in Afghanistan is better than it has been for 30 years.

Even so, the country cannot successfully be reconstructed without the full return of normal security. With that in mind, a major part of assistance from the United States and other donors is going toward rebuilding the Afghan Army (expected to have 10,000 soldiers by the summer of 2004) and a national police force (expected to have 20,000 officers by the summer of 2004). Another program, referred to by the initials "DDR," is designed to demobilize, disarm and rehabilitate thousands of militiamen.

The United States has established a comprehensive program for the training of all Afghan police, including some women, by December 2005. Each training course in this program includes democratic policing, community-based policing and knowledge of and protection of human rights as well as women's rights. Recruitment of the police has been on a non-discriminatory basis, and a special program to encourage the hiring and mentoring of women officers has been instituted. The United States has also committed to maintaining a civilian police model for the Afghan National Police, removing military and paramilitary forces from day-to-day policing. The civilian police model encourages protection of human rights, and will enhance security throughout the country.

To support the Afghan government's efforts in this regard, the United States has deployed Provincial Reconstruction Teams (PRTs). PRTs combine military civil affairs teams with a small force protection element, as well as Department of State and USAID personnel. Representatives from the Afghan Ministry of Interior are also present in many of the PRTs. The United Kingdom, Germany, and New Zealand are also leading PRTs. The first six PRTs were established in Gardez, Bamiyan, Mazar-e-Sharif, Kunduz, Kandahar, and Parwan. The Coalition and NATO now have 13 PRTs in operation, and expect to set up three new ones by September. These groups are having a positive impact on security in the provinces. The FY 2004 Supplemental contains an additional \$50 million for PRT reconstruction projects, which will play an increasing role in our Afghan security strategy.

Significantly, addressing the special needs of women and girls is part of the mission of the PRTs. In Kandahar, the local unit is renovating the women's dormitory at the university; the team in Kunduz is rehabilitating women's facilities at the Teacher Training Institute; and in Mazar-e-Sharif, the local team is rebuilding a women-sponsored silkworm production factory. We expect other such reconstruction projects focused on women to be proposed for targeted funding in the near future.

\section{Violence Against Women}

One important aspect of U.S. support for the reconstruction effort is ensuring the human rights of Afghan women. Under the Taliban, violence against women was the systematic policy of the Afghan regime itself. Today, while the Afghan government is firmly committed to ending such violence, problems nevertheless remain, due to certain traditional social customs and practices, or to shortfalls in enforcement capabilities. The crucial difference is that now, in stark contrast to the situation under Taliban rule, Afghanistan's political system is committed to a sustained campaign to combat and prevent abuses against women.

During the past year, as lawlessness and sporadic fighting continued in some areas outside Kabul, violence against women persisted, including reports of beatings, rapes, forced marriages, and kidnappings. Many such incidents probably went unreported, and most information was anecdotal. It is difficult to document the incidence of rape, in particular, in view of the social stigma that surrounds it. According to the State Department's Human Rights Report, a climate of secrecy and impunity increases the likelihood that domestic violence and rape against women could remain a serious problem.

The Human Rights Report states that, in 2003, approximately 100 women were imprisoned at the request of a family member throughout the country. Some of those incarcerated opposed the wishes of their families in the choice of marriage partners. Others were accused of adultery. Some faced bigamy charges from husbands who granted a divorce only to change their minds when the divorced wife remarried. Other women faced similar charges from husbands who had deserted them and reappeared after the wife had remarried. Kabul's Police Chief said that the police would continue to arrest women if their husbands or family brought complaints to the authorities.

Despite these persistent problems, the UN Secretary General's December 2003 Report on Afghan Women acknowledges progress on women's human rights. The report commends the Afghan government's formal legal commitment to women's security and equality, as well as the work of the Afghan Independent Human Rights Commission (AIHRC), which is chaired by the former Minister for Women's Affairs and includes five 
women:

The Women's Rights Unit of the AIHRC continues to ensure that women's rights are fully mainstreamed and works closely with other commissions and ministries to ensure the integration of human rights concerns and programs throughout these bodies. Additionally, an Advisory Group on Human Rights has been established and serves as a forum for assessing the human rights situation, in particular the rights of women and girls, and establishing benchmarks for the government's implementation of basic human rights concepts and international human rights instruments.

\section{Trafficking}

According to the Department of State's Office to Monitor and Combat Trafficking in Persons, there are reports suggesting that some Afghan women and children may be at risk of being trafficked for sexual exploitation or forced labor. Afghanistan's President Hamid Karzai has spoken out against trafficking in persons, appointing a Commission to address the issue with neighboring countries. Several government offices also provide assistance to hospitals and NGOs that protect trafficking victims.

The United States continues to encourage the Afghan government to expand its cooperation with NGOs and international organizations to protect victims, while enhancing collaboration among law enforcement agencies and NGOs. The State Department's Office to Monitor and Combat Trafficking in Persons has funded a survey, conducted by the International Organization of Migration, to evaluate the scope and magnitude of Afghanistan's trafficking problem, and to recommend on how best to address any problems that emerge.

Afghan authorities made multiple arrests of alleged traffickers and rescued trafficked children during the year. An inter-ministerial committee was also established to combat child trafficking, and began work on a national action plan. Police and other government officials underwent sensitization and training workshops on human trafficking.

Afghan women, as well as men, are increasingly benefiting from all of these efforts to improve the security situation, not just in Kabul, but also across most of the country. The United States remains committed to working with Afghanistan to increase the country's security.

\section{AFGHAN WOMEN'S POLITICAL AND CIVIC PARTICIPATION}

Afghanistan has achieved some remarkable political milestones during the past year. The most significant is the Constitution ratified on January 4, 2004, by Afghanistan's Constitutional Loya Jirga (CLJ). The CLJ was the culmination of a lengthy drafting and consultative process leading to the first modern democratic Constitution for Afghanistan. The Constitution gives the right to vote to all citizens, men and women, and guarantees freedom of expression, assembly, and religion.

Afghan women achieved a significant gain with the Constitution's specific mention of women as citizens. In addition, U.S. efforts will continue to focus on training initiatives so that women can serve effectively in the National Assembly seats that have been designated for women. The Constitution also provides for the state to render necessary assistance to women who have no caretakers, and for physical and psychological support for families. In helping Afghans to build a democracy and civil society, the United States will maintain support for projects that foster women's political leadership and participation.

\section{The Constitutional Process}

Women's active participation in the Constitutional Loya Jirga (CLJ) represented an exceptional political high point. Just over 100 of the 500 delegates were women. They lobbied successfully to have a woman appointed as one of four deputy chairpersons for the CLJ. Women played important roles and took leadership positions throughout the constitutional process; their participation was an integral part in strengthening human rights provisions in the Constitution. Nearly every woman involved in the January 2004 Constitutional Loya Jirga, and in the Emergency Loya Jirga in 2002, received some training through our projects.

During the 2004 CLJ, women were able to question leaders openly and discuss their aspirations for political change, which sparked some tension. For example, during the debate on whether a woman deputy chairman should be appointed, the Chairman implied that two women were equal to one man under Islamic law (though some of his supporters later said he was only trying to use humor to defuse a volatile situation). Another incident involved a woman delegate from Farah, who accused several of the delegates of human rights abuses, provoking several delegates to call for her ejection from the CLJ. The Chairman initially called for her removal, 
but others intervened on her behalf and she was allowed to stay. UN representatives provided her protection for the remainder of the CLJ, and she has since returned home where she continues to voice her views.

While these incidents reflect the social obstacles to equality that Afghan women face, they also demonstrate the personal courage and determination of Afghan women to take their rightful place in a new Afghanistan. Afghan women are discovering that restrictive or abusive cultural traditions are not necessarily rooted in Islamic doctrine, but rather in patriarchal customs or political convenience. As such, these restrictions can be challenged through a democratic process.

\section{The Upcoming National Election}

In July 2003, President Karzai established the Interim Election Commission to register voters and implement other preliminary steps in preparation for the Fall 2004 elections. The Interim Commission has six members, two of whom are women. Special programs have also been implemented that target women voters, to further educate them on the importance of voting and political participation.

As of early June, about 2.8 million voters have been registered across Afghanistan, out of an estimated eligible population of seven to nine million. Nearly a third of the voters registered so far are women. The UN is deploying voter registration teams to over 4,500 locations, many in small villages and in difficult terrain. In the major provincial cities of Herat and Mazar-e-Sharif, where U.S.-supported women's radio stations operate, 48 percent of women have registered to vote - considerably higher than the national average thus far. To support democracy and the elections, the United States has designated \$139.3 million as part of the "Acceleration Success" funding to provide technical assistance to the Constitutional Commission, the Constitutional Loya Jirga, and the upcoming national election. Since 2002, USAID has provided a total of $\$ 78$ million in direct support for Afghanistan's overall electoral process, including funding for relevant projects conducted by leading NGOs such as the International Foundation for Electoral Systems (IFES), the Asia Foundation (TAF), the National Democratic Institute (NDI) and the International Republican Institute (IRI).

In addition to the above, Afghan women have achieved other important political milestones. The Cabinet includes two women Ministers; many more women serve throughout the government; two of the nine members of the Constitutional Drafting Committee and seven of the 35 members of the Constitutional Review Commission are women; and thousands of women participated in the public consultations on the Constitution. To foster and strengthen the rule of law, the United States offered technical assistance, financial support, equipment and advice to the Judicial Reform Commission for development and revitalization of the judicial system. (See also U.S.-Afghan Women's Council program for women judges below.)

\section{Local Government and Civil Society}

The United States has also dedicated $\$ 10$ million to develop a community empowerment initiative that ensures women's participation in local governance, builds the capacity of women's community development councils, oversees women's block grants issued by the Ministry of Rural Rehabilitation and Development, and supports the coordination of multiple activities and services for women at the community level. The program provides a venue for women to participate in governance issues, have access to services (such as literacy, health education, early childhood development, vocational training and micro-credit), and develop cooperative enterprises.

Above and beyond formal political institutions and processes, the development of an Afghan civil society is critical to sustainable peace. The past year witnessed an increase in grassroots NGOs, including those supporting women's rights. The United States plans to continue funding for the development of private independent media, civic education, and political party development, as well as civil society institutions such as indigenous NGOs engaged in public advocacy work.

\section{The Afghan Ministry of Women's Affairs}

In FY 2003, the U.S. provided \$1 million to help fund the Ministry of Women's Affairs, and additional funds for the new Office of Women's Issues, International Cooperation and Human Rights in the Afghan Ministry of Foreign Affairs. The United States continues to actively support the work of these ministries, with project funding and technical assistance as well as political backing.

The Ministry of Women's Affairs encompasses five departments: legal services and advocacy, education, vocational training, women's health and communications, and planning and international relations. The Minister of Women's Affairs prioritized the construction of Provincial Women's Centers (PWCs) in 17 of the 34 Afghan 
provinces, with an additional Center already established inside the Ministry building in Kabul. As the 17 provincial centers are built, they will replace the current rented facilities. The Centers will provide educational and health programs, job skills training and political participation training to women. As of late April 2004, three of the centers were completed and construction is underway on two others. U.S.-funded programs for these Centers will soon be announced from the open competition for proposals, managed by the Department of State's Bureau of Educational and Cultural Affairs (ECA) (See section 5 for details).

At the same time, U.S. programs aim to ensure that Afghan women are involved in the work of all ministries. For example, USAID has constructed kindergartens in nine different ministries in Kabul, providing safe childcare to help working mothers participate in governance.

\section{THE U.S.-AFGHAN WOMEN'S COUNCIL}

While the public sector plays a critical role in mobilizing resources, the United States also recognizes the valuable skills that the private sector can contribute to Afghanistan. For this reason, in January 2002, President Bush and President Karzai established the U.S.-Afghan Women's Council (USAWC) to bring together Americans and Afghans to undertake projects that meet the needs that Afghan women themselves have identified as most crucial. The Council is managed by the State Department's Office of the Senior Coordinator for International Women's Issues and is designed to forge bi-national, public-private partnerships to fill gaps in the array of official programs benefiting Afghan women. The Council has proved to be an important tool for mobilizing government offices, NGOs, the business community, and individual citizens to understand the problems facing Afghan women, and to work together voluntarily on practical solutions. The Council alternates meetings between Washington and Kabul, and the fifth session is scheduled for June 2004.

The Council is co-chaired by the State Department's Under Secretary of State for Global Affairs and the Afghan Ministers of Foreign Affairs and of Women's Affairs. Members include distinguished scholars, NGO leaders, business executives and government officials. No fewer than 10 Afghan Cabinet ministers attended the Council's February 2004 meeting in Kabul--a testament to the Council's success in raising the salience of women's issues.

At the February 2004 meeting, Council members reviewed programs and progress on implementation of initiatives in the educational, political, and economic sectors of Afghan reconstruction. Discussions focused on the new constitution and the upcoming elections in 2004. The delegation visited a women's literacy center, and met with project managers of a variety of U.S.-supported programs. The Council also agreed to support a number of specific initiatives, such as an American School in Kabul, a teacher-training institute for women, the women's component of the Afghan Conservation Corps, and a \$5 million, USAID-funded project to train midwives throughout rural Afghanistan. In addition, the Council stressed the need to move forward with the construction of 17 Women's Resource Centers.

Through a $\$ 10,000$ donation to the U.S.-Afghan Women's Council from Daimler-Chrysler, the Foundation for International Community Assistance (FINCA), a non-governmental organization, will establish two village banks in Herat Province. With a new contribution of $\$ 25,000$, FINCA is now opening five more village banks, and expects to assist more than 30,000 clients in Afghanistan over the next 5 years.

Also through the Council, the United States has provided more than $\$ 500,000$ to train women journalists and filmmakers. The "Afghanistan Unveiled" documentary film project included an Afghan Women's Oral History initiative and training of women journalists. Conducted in partnership with the Asia Foundation, the National Geographic Society, and the Kabul office of the French-based NGO "AINA," this project created jobs for women in the media and sustained revenues for AINA to continue its work to create a free and independent media in Afghanistan. And the Public Broadcasting Service (PBS) gave $\$ 20,000$ to AINA for broadcast rights to the film "Afghanistan Unveiled."

In addition, women executives of AOL/Time Warner have raised $\$ 60,000$ for the Council's Gift Fund to support a provincial women's resource center, and Members of the Council are contributing resources, expertise, and equipment for skills training and similar projects. This summer the Thunderbird School of International Management in Arizona will offer a special program of courses and career development support to a group of talented Afghan women, who would probably not otherwise be able to obtain such high-level and prestigious credentials.

In early 2004, the Council announced and is now finalizing operational details of a relatively ambitious project to support the educational programs and exchanges with the provincial Women's Resource Centers. This project, using $\$ 1$ million in funds designated by Congress and implemented by State's Bureau of Educational and Cultural Affairs, will carry out a series of educational programs in critical issue areas for women, including job skills training, microfinance, political participation, human rights education, and literacy. 
The Council also maintains a dynamic presence on the worldwide web, responding to a steady stream of inquiries about opportunities to aid Afghan women. Several firms, foundations, and associations have offered financial or other support for worthwhile women's projects. The list so far includes: Gateway Computers, Grafik Communications, Ltd., Daimler-Chrysler, Smith-Richardson Foundation, American Association of State Colleges and Universities, Fortune 500 Group, the Fortune 500 Most Powerful Women, the Committee of 200, and others.

In cooperation with the Department's Bureau of Educational and Cultural Affairs, the Council supports an intensive teacher-training exchange for Afghan women at the University of Nebraska in Omaha, which has long hosted an Afghan Studies Center at a U.S. institute of higher education. Through this initiative, a group of approximately 45 Afghan women have become certified as master teachers and trainers, prepared to return to their homeland and inculcate these new-found pedagogic skills and values among their peers.

The Department of State, the NGO Afghan Women Leaders Connect, with support from the U.S.-Afghan Women's Council, are also currently funding a project for the International Association of Women Judges to train a group of four Afghan women judges this summer. Afghan women recognize that judges will play a key role in ensuring that equal rights become a reality for Afghan women. Another member of the Council has launched a promising micro-enterprise cooperative for Afghan women to make and export high-quality rugs. The first orders for rugs from this project (called "Arzu," the Dari word for "Hope") have already been placed.

These projects and others initiated under the Council's auspices are deliberately small in scale -- but large in impact, in terms of both public profile and social returns. The Council's unique "value added" lies in its ability to fill niche requirements that might otherwise go unmet, even as it fosters creative, grass-roots collaboration in the cause of Afghan women's advancement.

\section{ECONOMIC SECTOR: U.S. DEVELOPMENT PROGRAMS FOR AFGHAN WOMEN}

\section{Women as Part of the Overall Economy}

Afghan women have identified jobs as one of their most important concerns, and that is why U.S. programs stress education and skills training as a top priority. Economic progress is essential to political and democratic progress, and to the struggle for stability and drug eradication. The degree of success achieved by a broad national reconstruction and revitalization program will be a crucial determinant for the future of women, children, and refugees.

Repair and construction of basic infrastructure are essential to economic life in Afghanistan. Major infrastructure projects with U.S. and other support are underway around the country, including the KabulKandahar-Herat Ring Road construction and many small-scale road projects. In December 2003 the first step toward reconstruction of Afghanistan's national road system was completed. Phase I of the 389 kilometer (241 miles) highway linking Kabul to Kandahar is now open to traffic. As a result, men and women enjoy better access to markets, healthcare, schools and jobs. At the national level, the highway has already begun to contribute to Afghanistan's improved economic growth, security and national unity. The United States is encouraging greater involvement by multilateral development banks and others in additional construction projects, including quick impact public works such as the rebuilding of local roads, bridges, schools, and irrigation systems.

From the ruins of a quarter-century of conflict, Afghanistan's new leaders have steadily advanced economic policy, implementing a stable new currency in 2002, passing a strong banking and investment law in 2003, and adopting an overall national development strategy that recognizes the need to work toward sustainability by limiting spending and boosting revenues.

These efforts, combined with the increasing interest in the private sector (particularly from the Afghan diaspora), have helped Afghanistan show strong economic results over the last two years. Unofficial IMF/World Bank estimates put current annual growth between 20-30 percent driven by the agriculture, construction, and services sectors. However, privatization has been slow to occur. Afghanistan remains heavily reliant on the international donor community. Another problem is the residual communist factions in the government that remain anti-market. The longer it takes Afghanistan to privatize its state-owned enterprises, the more difficult reform will be.

In all of these efforts to better the economic outlook for Afghanistan, a guiding principle is to seek the involvement of women at every stage of reconstruction -- as planners, implementers, and beneficiaries. The objective is to ensure that Afghan women and children share fully in the improved quality of life that will accompany Afghanistan's economic development. Alongside this broad economic support system, the United 
States is engaged in a myriad of smaller-scale but intensively focused job training, income generation, microcredit, and related projects targeted particularly toward the women of Afghanistan.

\section{Targeted Economic Programs}

Afghan women still face many difficult challenges, which inhibit their ability to participate in economic life. Seclusion, widespread illiteracy, and lack of job skills make it difficult for women to be economically active. Therefore, many donor programs focus on job skills training and microfinance for women and a significant number of programs target widows and the particularly vulnerable female-headed households. Examples of such programs follow:

- The United States provides $\$ 3.5$ million for private sector development training for women, including programs to educate women on their property and other rights under Islam and to help them navigate legal and administrative processes.

- Other projects provide skills and literacy training for widows and female heads of household; teach women in animal husbandry, including improved poultry production techniques in 250 villages; train women in tailoring; teach women to preserve produce and dairy products for local sale; provide technical support to women's carpet and textile projects; and fund bakeries that employ widows and provide subsidized bread to hundreds of thousands of urban poor.

Similarly, U.S. strategy for providing humanitarian relief gives priority to the most vulnerable groups, including women and children. Through international organizations and NGOs, as well as direct support to the Afghan government, the United States supports programs that include training, primary, preventative and maternal health care, and income generation projects.

\section{HEALTH SECTOR: PROGRAMS FOR WOMEN}

\section{Health Conditions of Afghan Women}

Years of conflict and deprivation have left Afghanistan with the second highest maternal mortality rate in the world (1,600 maternal deaths per 100,000 live births), and significantly high child mortality (one in four children dies before age 5 ). Access to basic health care could have prevented many of these deaths, but currently over $90 \%$ of Afghan women deliver their babies without trained medical assistance. Adult life expectancy is barely 46 years, and even lower for women.

In the short term, the United States has put a priority on rebuilding health clinics and schools, training midwives and teachers, and providing supplies, such as textbooks and medical equipment. Even in rural areas, basic health services are now available to more than 2.5 million people in 21 provinces; 90 percent of the recipients are women and children. To date, the United States has rehabilitated or constructed 140 health clinics throughout Afghanistan, including rural areas; we expect to double that number during 2004. In the longer term, the goal is to build the capacity of the Afghans themselves to sustain these positive changes.

\section{U.S. Programs To Improve Maternal Health}

The United States has financed health care programs in Afghanistan totaling more than $\$ 58$ million, with $\$ 50$ million more forthcoming over the next two years. These programs include the construction of women's wings in hospitals and dormitories for women medical students; curriculum development for health care workers; and maternal and child health, family planning, and nutrition programs.

The overall objective is to improve the basic health and nutrition of Afghans, particularly women, children, and displaced persons. A whole panoply of projects bringing basic services and health education to underserved communities, focusing on maternal and child health, hygiene, water and sanitation, immunization and control of infectious diseases. In these programs, women are the primary recipients of services, and well as providers of health care. More specifically, the U.S. is improving the health and welfare of mothers and children through programs that focus on establishing safe supplies of drinking water, eradicating polio and measles, instituting a national public health center, and implementing nutrition initiatives to combat widespread malnutrition. USAID has rehabilitated 140 health facilities (clinics, birth centers, feeding centers, and hospitals, and currently has 72 new clinics under construction. Basic health services are now being provided to over 4.8 million Afghans, mostly through NGOs.

The Rural Expansion of Afghanistan's Community-based Healthcare (REACH) program is significantly reducing 
maternal and child mortality and morbidity in Afghanistan. Of the $\$ 52$ million total funding for REACH in FY 2004 , over $\$ 10$ million is being given in grants for the delivery of health services by local women-focused NGOs and to vocational training for women as community healthcare workers and midwives. Over the next three years, REACH plans to provide the Ministry of Health's basic package of health services to an estimated $11,000,000$ Afghans.

Maternal and newborn healthcare programs sponsored by the United States have provided training for community health workers in recognizing complications during pregnancy and situations warranting referral for more specialized treatment. Other programs include "Learning for Life,"

an accelerated health focused literacy program, which will allow some 5,500

women in 13 rural provinces across Afghanistan to qualify for training to become community healthcare workers, community midwives, and midwives. The program was just launched by Ambassador Khalilzad in February 2004. The first class of 25 midwives graduated in April 2004, and six more classes of equal size are underway.

U.S.-funded programs also include purchase of contraceptives ( $\$ 2.5$ million), and buy-ins to UNICEF's polio eradication program (\$1.5 million), the universal salt iodization to combat iodine deficiency $(\$ 250,000)$, and the World Health Organization's malaria prevention program $(\$ 500,000)$. The Global Displaced Children and Orphans Fund (DCOF) is also providing \$2 million for the care and protection of war-affected children and \$1 million from the Victims of War Fund is being used in a pilot program to train orthopedic technicians and provide support to fledgling Afghan disability councils.

\section{EDUCATION SECTOR: PROGRAMS FOR WOMEN AND GIRLS}

Women were systematically denied opportunities for education and vocational training under the Taliban, and female illiteracy was widespread even before the Taliban. According to preliminary data from UNICEF, $71 \%$ of Afghans nation-wide are illiterate (defined as 15 years of age and above). Female illiteracy countrywide is $86 \%$. The situation is especially dire in rural areas, where $92 \%$ of women are illiterate. It is essential that the donor community conduct intense efforts to improve literacy rates and vocational proficiency and professional opportunities for women. A wide range of U.S. Government programs in Afghanistan are focused on improving primary education for Afghan boys and girls, and on literacy and job skills education specifically for women. This section focuses on women and girls; additional educational programs will be described separately in the section below on children.

Through decades of conflict, approximately $80 \%$ of Afghanistan's schools were damaged or destroyed, and over 8 million Afghans ranging in age from 6 to 30 had little or no education. To date, 205 schools of all types have been rebuilt (or built from scratch), 25 million textbooks have been provided, and 7,000 teachers have been trained. In 2003, according to the Afghan Ministry of Education, 5.8 million children attended school. Thirty five percent of these students were girls - by far the highest number in Afghan history. The Afghan Ministry of Education aims to have girls make up 50 percent of the student enrollment.

USAID has sponsored over 200 reconstruction or rehabilitation projects for multiple primary and secondary schools in various regions of Afghanistan, as described further in the following section. Of those, more than 14 are specifically girls' schools. Over 23,000 girls have already benefited from the various school construction projects sponsored by USAID-for the first time in their lives they have the chance to attend school.

A primary barrier to education for girls is physical access to schools in many areas due to the poor road conditions. USAID has sponsored a number of construction projects aimed at improving access to schools, including construction of culverts along the Walai access road to the Kolangar girls' school, a project which benefited 200 female students.

The USAID-supported the Afghan Primary Education Program (APEP) has set aside \$20 million of a total \$95 million in FY 2004 to provide accelerated learning for girls, train female teachers, provide textbooks for girls in both the formal and informal school systems, and provide vocational training for women. A special program provides extra food rations as incentives for families to keep their daughters in school. In addition, the USAID Mission is contracting the reconstruction of a women's dormitory ( $\$ 9$ million) that will house 1,000 women from rural areas and allow them to reside in safe surroundings while they attend University of Kabul and/or the Education University.

The U.S.-Afghan Women's Council, the Bureau of Educational and Cultural Affairs (ECA), and the NGO World Learning plan in the coming weeks to conduct a leadership-training program for Afghan women. Working with the Women's Resource Center in Kabul, six participants will be selected and given a five-day training and orientation program. The participants will then travel to the United States and participate in a two-week program at Bluefield College in West Virginia, where they will develop action plans focusing on using leadership in 
government, NGO's and business. A weeklong training program will follow in Washington, DC. During this phase the participants will continue to work on their action plans. Upon their return to Kabul, the women will implement their action plans and conduct leadership training at the women's resource centers.

The USAWC and ECA will soon help administer a program through the Institute for Training and Development. This program will enhance the capacity of ten Afghan women who are adult educators or managers of educational services, preferably from non-governmental organizations and individuals working with the Women's Resource Centers, to educate women and out-of-school girls and to manage the educational services provided by their organizations. This is due to be carried out in a three-phase program, which includes assessment, and recruiting, a three-week U.S. based training program and an in-country implementation phase.

Another initiative administered under the auspices of USAWC and ECA is through the American Councils for International Education (ACIE). This upcoming 18-month project features several phases to expose Afghan educational administrators and community leaders to different approaches in education and literacy training. ACIE will work in partnership with California State University at Chico (CSU Chico) and several organizations in Afghanistan--Refugee Women in Development (RefWID), Aid Afghanistan, and Afghans for Civil Society--to carry out the project.

\section{AFGHAN CHILDREN: SAVING THE NEXT GENERATION}

The situation of children in Afghanistan is still generally poor, despite the efforts of local and international organizations to ensure their welfare. The infant mortality rate is one of the highest in the world, and one-fourth of children born die before reaching age five. Even so, as many as $45 \%$ of Afghans today are children under 14 years old.

The United States continues to mount a major response to the daunting challenge of enabling Afghans to better care for their children. The focus, as described elsewhere in this report, is on the provision of primary healthcare and primary education. Fortunately, preliminary statistics in both these core areas, particularly in education, show significant improvements during the past year. Massive inoculation and other preventive health campaigns to combat endemic childhood diseases promise medium-term improvements, possibly of dramatic proportions. Yet given the scope of Afghanistan's needs in these areas, these concerns will almost certainly remain a central preoccupation of U.S. reconstruction strategy for the foreseeable future.

\section{Afghan Children's Education: An Overview}

The opportunities for Afghan children's education, especially for girls, have improved dramatically thanks to U.S. support under the Karzai government--no small achievement after the serious and systematic abuses of the Taliban regime. Girls flocked to schools when they re-opened in March 2002. The Ministry of Education has publicly announced a commitment to increasing girls' enrollment further still, and UNICEF has announced a goal of an additional 500,000 girls enrolled in primary schools by the end of 2004 .

Educational opportunities in Afghanistan vary significantly among the country's different regions. Cultural barriers to educating girls persist, more strongly in some areas than in others, and are heightened by a lack of trained teachers, especially women teachers. Physical limitations such as insufficient or inaccessible spaces and structures, lack of access to safe water, lack of books and other materials, and inadequate sanitation mechanisms provide further barriers to educating all Afghan children. In many areas of Afghanistan, classes are held out-of-doors without books or materials.

\section{U.S. Efforts to Improve Children's Education}

The United States has helped rebuild and rehabilitate over 200 schools to date--and plans to extend this work to include at least 275 more in 2004. Longer-term plans cover a total of 1,000 schools and training for teachers, mostly women, as part of a package of $\$ 61$ million in support for primary education over the next three years. Working with various NGO and UN partners, the United States aims to continue the important progress achieved in the last year through projects directed towards teacher training, especially training women teachers, and improved access roads and buildings for girls schools, among other projects. Education is also a key component, as noted above, of the programs being devised and implemented by and through the U.S.Afghan Women's Council.

\section{Children's Health Programs}

Since the fall of the Taliban, the United States has devoted particular attention to improving the health care of 
the children of Afghanistan. Specific health programs for them include:

- USAID grants to UNICEF to treat 700,000 cases of malaria, offer measles vaccinations for 4.26 million children, and conduct a polio surveillance and vaccination campaign. USAID has also supported a campaign to reduce diarrheal diseases through Population Services International.

- Health education programs sponsored by the State Department's Bureau of Population, Migration, and Refugees (PRM) for Afghan refugee children, in partnership with Save the Children (UK).

\section{AFGHAN REFUGEES: RETURNING HOME}

The repatriation of Afghans since October 2001 represents a major success of the international community's efforts. Afghan refugees have seen the results of efforts of the transitional government and international community to bring stability, peace, and prosperity to Afghanistan. According to UN estimates, almost 3 million Afghan refugees have returned to their homeland since the fall of the Taliban in December 2001, and UNHCR expects that an additional one million refugees will return to Afghanistan during 2004. In addition, approximately 200,000 internally displaced persons (IDPs) inside Afghanistan (out of an estimated total of 700,000) were assisted in returning to their homes or to a location of their choice during 2003; about the same number appear to have returned home on their own, bringing the total to over 650,000 since early 2002 .

To support these returnees, the State Department's Bureau of Population, Refugees, and Migraton has obligated, since September 2001, almost $\$ 290$ million in support of assistance and protection programs for Afghan refugees and returnees. Many of the beneficiaries of these activities are women and children.

As evident from the program notes and budget figures in the Appendix to this Report, the State Department continues to contribute heavily to this successful repatriation and resettlement effort. The vast bulk of these funds are channeled through such agencies as the United Nations High Commissioner for Refugees (UNHCR), the International Organization for Migration (IOM), the International Committee of the Red Cross (ICRC), and many NGOs. The State Department's Bureau of Population, Refugees, and Migration (PRM) is the lead agency on refugee programs for the USG. Examples of PRM support of NGO programs include:

- A program with Women for Women International that brings skills training, income generation, and rights awareness to women in Kabul, Wardak, and Parwan provinces.

- A reproductive health program with American Refugee Committee in which provides training and emergency obstetrical care for women in Afghan remote camps in Baluchistan.

- A program with the Aga Khan Foundation providing durable shelters, latrines, and maintenance training for homeless Afghan returnee families in Baghlan and Kunduz Provinces Afghanistan.

- An Afghan refugee education program in Pakistan's North West Frontier Province (NWFP), benefiting 25,000 children (71\% of them girls) and 900 Afghan teachers.

The United States continues to support UNHCR and other partners assisting and protecting the approximately 2.5 million Afghan refugees still outside the country, in order to help ensure that repatriation remains gradual, manageable, and voluntary. Based on trends over the past few months, UNHCR projects that it will facilitate the return of about 1 million additional Afghan refugees this year.

It is also noteworthy that, with U.S. support, UNHCR has moved to institutionalize greater gender sensitivity in its Afghan operations. Female UNHCR staff, including Afghan women, is present at all entry points and other facilities. Contracts with implementing organizations require that women be included as decision-makers on matters regarding both shelter and water wells, and that wives or widows be included on benefits documentation.

Security has become a growing concern for workers involved in refugee and other humanitarian organizations in Afghanistan, especially in the south and southeast of the country. The Afghan government recently 
announced the formation of a special committee within the Cabinet to address this problem.

As more returnees and IDPs relocate to their homes, the United States will work to ensure that their needs are not neglected because international attention has shifted elsewhere. The United States will cooperate closely with other donors to make sure Afghan refugee assistance programs continue, for both humanitarian and stability/security reasons. Indeed, this aspect of our overall effort in Afghanistan has been cited by the U.S. Embassy in Kabul as one of its long-term strategic goals.

\section{CONCLUSION: THE ROAD AHEAD}

The United States can take considerable satisfaction from our successful efforts to support Afghan women since the Taliban's overthrow. Still, it must be acknowledged that much more is yet to be done. Implementing the new Constitution, which is one of the most progressive on women's human rights of any in the entire Muslim world, is one of many challenges ahead for women in Afghanistan. It will take time and effort to translate this model document into living, lasting reality. In particular, the full participation of women in the Afghan national election scheduled for September 2004 will be an early and important measure of their readiness to retain the new political leadership roles they have shouldered, with strong U.S encouragement and assistance, since their liberation from Taliban tyranny. But what is equally important is that Afghan women very much need and want the knowledge and skills, not only to run for political office, but also to improve the quality of health care and education for their families, tackle legal reforms, and create economic opportunities.

Among the most pressing issues are illiteracy among women and girls, infant mortality (among the highest rates in the world), and the need for job skills training for economic self-sufficiency. Security problems still limit women's freedom of movement, as do cultural biases against women's participation in public life. To improve women's rights, the United States has addressed the specific needs of women in all of its reconstruction programs and implemented projects to increase women's political participation, role in civil society, economic opportunities and education. The United States also supports the Ministry of Women's Affairs efforts to establish in each of Afghanistan's 34 provinces a network of women's resource centers, places that will provide a safe place for women to receive vocational training and a range of other educational and social services.

Reconstruction efforts in Afghanistan thus far have been a model of international cooperation and have engendered much goodwill between the Afghan people and the international community. The United States looks forward to Afghanistan's first Presidential and parliamentary election, and will work together with the Afghan government and the United Nations to ensure that Afghans will be able to exercise their democratic rights, free from violence and intimidation. In Berlin, the United States - already Afghanistan's largest donor nation - announced its pledge of $\$ 1$ billion, reaffirming our long-term commitment to Afghan reconstruction. The new pledge brings the total USG pledges for 2004 up to $\$ 2.2$ billion, bringing our commitment to Afghanistan over the past three years to over $\$ 4$ billion.

Americans are sending a strong, unmistakable signal of support for Afghanistan. The United States looks forward to strong and unmistakable signals also from the international community, which must continue providing needed support for Afghanistan's reconstruction until the country is on the path to self-sustaining economic growth. The United States is committed to working with the people of Afghanistan to set Afghanistan firmly on the path to security, democracy and sustainable economic growth.

As Under Secretary of State for Global Affairs Paula Dobriansky said in Kabul during the February 2004 meeting of the U.S.-Afghan Women's Council, "We can take some pride in what we have already accomplished, but our work in Afghanistan is far from finished."

This site is managed by the Bureau of Public Affairs, U.S. Department of State.

External links to other Internet sites should not be construed as an endorsement of the views contained therein.

Copyright Information | Disclaimers 